\title{
The Social and Political Dimensions of Solidarity in Italy
}

\author{
Nicola Maggini
}

\section{INTRODUCTION}

This chapter explores the social and political dimensions of solidarity in Italy, measuring solidarity practices in their various aspects and explaining them with reference to core socio-demographic and attitudinal factors. Understanding the spread and the triggers of solidarity practices in the Italian context is a goal that deserves scholars' attention due to the various crises that have affected the country since 2008. Indeed, the global financial crisis and the austerity measures which followed have resulted in drastic cuts to public services, heavy job losses, and reduced incomes. The impact of the crisis on the most vulnerable sectors of society, such as people with disabilities, was particularly tough. In this regard, the most evident and tangible outcome of the crisis was the cut in the "National Fund for the Non-Self-Sufficient". Reduced by $75 \%$ due to budget cuts in 2011 , the Fund was not financed at all in 2012. While governmental action has focused on fiscal containment and consequent public service retrenchment, societal needs have not only intensified (as the number of people in need has increased) but also diversified (due to socio-demographic changes

\footnotetext{
N. Maggini $(\bowtie)$

University of Florence, Florence, Italy

(C) The Author(s) 2018

C. Lahusen, M. Grasso (eds.), Solidarity in Europe, Palgrave Studies in European Political Sociology, https://doi.org/10.1007/978-3-319-73335-7_6
} 
and global socio-economic processes). Within the gap of a few years, the refugee crisis overlapped with the economic crisis, strongly affecting a country positioned at the centre of several migration routes in the Mediterranean Sea. According to UNHCR estimates, from January until December 2014, the total number of sea arrivals reached 170,000, almost one-third of whom were rescued by the operations "Mare Nostrum" and/or "Frontex's Triton". A new record was registered in 2016, when the total number of sea arrivals reached 181,000: an 18\% increase compared with 2015 (154,000). Several thousands of people perished at sea. Solely in 2016, the number of people who lost their lives was 5022. Finally, 2016 data also highlight Italy's record for the number of landings in the Mediterranean: half of more than 361 thousand migrants arriving by sea into Europe landed on the Italian coast, $48 \%$ of the landings occurred in Greece $(174,000$ arrivals), while 8826 migrants landed in Spain. The increased inflow of refugees from Syria and other regions affected by wars and the inability of the EU institutions and its member states to establish a coordinated asylum policy and mechanisms of admission and integration have raised the concerns that solidarity between EU member states is severely at risk.

In such a difficult landscape, solidarity is under pressure. Indeed, the economic and refugee crisis are international challenges that call for joint action and mutual solidarity at the supra-national level. Yet, economic hardships, social inequalities, and lack of collaboration between national governments on the migration issue can increase nationalist sentiments and populist reactions, as shown by the success of populist parties, the Brexit vote, and the mobilisation of Eurosceptic and xenophobic protests across Europe. All this has raised further concerns about not only the weakening of solidarity between member state governments but also the deterioration of solidarity at the level of the European citizenry, especially in a country like Italy that faced multiple crises and therefore can be considered a relevant case study to explain factors which inhibit and/or strengthen solidarity actions. Unmet needs can take two main paths: disenchantment and resentment, deliberately exploited by political entrepreneurs, and resilience and social ingenuity, deployed through a range of civil society organisations, social movements, and social innovations. Do these paths mirror the current situation in Italy? How strongly is solidarity rooted at the individual level, both in terms of attitudes and practices, and how much are Italians engaged in solidarity-related activities? Is solidarity limited to specific target groups, or do we detect also a universalist or 
cosmopolitan philanthropy dimension? And which factors seem to trigger (or inhibit) solidarity practices? Public debate continues to address these solidarity issues, but we have had very little empirical evidence on which to draw to inform this debate to date. We are in need of empirical evidence in order to answer these research questions. This chapter makes this possible by drawing on data generated from an online individual survey conducted in November-December of 2016 (2087 cases for Italy).

The ultimate goal of this study is to enlarge and deepen knowledge on solidarity in Italy by providing new data and analyses on solidarity practices with respect to three target groups which have been particularly affected by the crises (the disabled, the unemployed, and refugees) and to explain such solidarity actions with reference to social traits of the respondents, their beliefs, and their political preferences. Previous research has not addressed these issues in any systematic manner, contrasting facts and observations have been taken into account, but a review of previous studies is important to comprehend the phenomenon under investigation by detecting relevant dimensions and aspects and by stressing explanatory factors that might affect solidarity practices.

First, previous research is conceptually important to start with a definition of "solidarity". In this regard, we agree with a strong strand of research that defines solidarity as the preparedness to share one's own resources with others (Stjernø 2012, p. 2). This definition emphasises the importance of attitudes and dispositions, which have received much attention in the social sciences. In fact, most surveys are primarily interested in measuring the readiness of citizens to share some of their resources with others. Moreover, survey-based studies measure solidarity by the citizens' approval of redistributional policies and, thus, by the readiness to allocate some of their taxes or contributions to the needy (Svallfors 1997; Fong 2001; Amat and Wibbels 2009; Rehm et al. 2012). Nonetheless, this focus on redistributional preferences is not without problems. Taxes and contributions to social security programmes are compulsory, and, therefore, support for social policies might not automatically bring up the readiness to commit individually in support for others. Furthermore, social psychology has stressed how attitudes and dispositions are not equivalent to actual practices (Blumer 1955; Festinger 1964; Ajzen and Fishbein 2005). Through our own survey, we aimed more explicitly to measure reported solidarity activities in order to get a more reliable picture about the extent to which Italian citizens are committed to supporting others, conceiving solidarity as practices of help or support towards others in struggle or in 
need, be that by personal contributions or by active support of activities of others, within informal and/or institutionalised communities.

Second, scholars have tended to privilege the charitable dimension of solidarity by focusing on the (financial) help to the needy. While this aspect is significant, it does not consider the political dimension of solidarity. In fact, people reveal solidarity with other needy persons when participating in collective actions (e.g. political protests, public claims making, lobbying, communication campaigns) that aims to improve the situation of these groups by mobilising public support, lobbying stakeholders, and/or changing public policies on their behalf (Giugni and Passy 2001).

Finally, previous studies are an important source of inspiration in order to identify factors that can influence solidarity practices. First, scholars have highlighted the importance of socio-demographic factors and social traits (e.g. age, gender, education, social class) for grasping the conditions, structures, and dynamics of solidarity (Hechter 1988). Some studies (Neill and Gidengil 2006; Valentova 2016) have shown that voluntary engagement tends to replicate the public/private divide by focusing especially on male-dominated and "public" activities. It has been revealed that younger and older citizens are more active in social movements, because of different levels of "biographical availability" in the life course (Beyerlein and Bergstrand 2013). Furthermore, different levels of commitment in solidarity actions can be patterned by citizens' differentiation in terms of personal resources and skills, such as income and education, by the respondents' social status and affiliation to social class (Verba et al. 1978; Cainzos and Voces 2010).

Second, education and subjective class position are also a measure of social centrality, usually linked to social capital, and previous research has shown that social capital measures are particularly important for our topic (Putnam et al. 2003; Jenkins 1983; Bourdieu 1986). In particular, we wish to highlight the role of interpersonal trust, informal networks, and social relations. The assumption is that social capital is the necessary "glue" of social cohesion (Chan et al. 2006; Jeannotte 2000; Delhey 2007), and it is tightly associated with values such as trust in others and with frequency of social connections. Several studies have shown that trust in others is associated with a wide range of positive outcomes in areas such as personal wellbeing (Helliwell and Wang 2010), crime rates, and even mortality rates (Lochner et al. 2003). Also, social trust can determine how much people in a society are willing to cooperate with one another, thus fostering solidarity actions. Similarly, having a good frequency of social 
connections fosters higher levels of life satisfaction and happiness (Lelkes 2010) but can also give people access to a wider range of possible support in times of need, producing positive outcomes at a community level (Halpern 2005).

Third, research on political behaviour in general, and on social movement and protest participation in particular, can help to answer the question of whether solidarity is determined by political factors. Indeed, we aim to identify the interrelation between political orientations on the one side and solidarity practices on the other. In this regard, studies agree on the fact that solidarity is also highly patterned by political preferences and ideological orientations (Blekesaune and Quadagno 2003; Amat and Wibbels 2009; Likki and Staerklé 2014). Among political factors, it is also important to consider political involvement in terms of interest in politics and party attachment because they are often associated with civic engagement (Scrivens and Smith 2013). The latter is another element that can help individuals to develop their skills and social values (such as trust in others), and, consequently, it can foster solidarity (Putnam et al. 1994).

Finally, we want to explore the role of ideational and cognitive factors, too. In particular, scholars have shown the importance of charitable dispositions linked to religiosity (Abela 2004; Stegmueller et al. 2012; Lichterman 2015) to explain different levels of solidarity. At the same time, we need to take into account that solidarity is attached not only to abstract universal communities - that is, humankind according to Arendt's political theory (Arendt 1972)—but also to specific reference groups. In particular, specific acts of solidarity seem to be conditional and thus tied to specific issues and target groups. In this regard, previous research has shown that perceptions of reciprocity, conditionality, and deservingness can play an important role as regards solidarity among the public (Oorschot 2000, 2006).

Based on these insights, the research is grounded on the hypotheses that social capital, political factors, religiosity, and perceptions of deservingness influence solidarity practices. In particular, we argue that there could be a distinction between triggers of solidarity towards specific target groups and triggers of solidarity in general. As regards the latter, we hypothesise that regardless of the target group, (a) the more an individual is socially embedded and trustworthy of others (the more her/his social capital), the more she/he will support people in need; (b) the more religious one is, the more she/he supports others in a "charitable" esprit; (c) the more a person perceives a group to be deserving of support, the more 
she/he will be disposed towards solidarity with that group. As regards group-specific triggers of solidarity, the refugee crisis has arisen innumerable initiatives not only to provide immediate help for refugees (e.g. clothing, food, shelter, language courses) but also to rally for migrant and refugee rights, sharing a universalistic and unconditioned notion of solidarity. The increasing inability of Italian authorities to handle the inflow of migrants and the growing mobilisation of populist, right-wing, and in part xenophobic groups boosted conflicts about the correct policies for the Italian government to pursue. Because of these conflicts, solidarity towards refugees became a contested issue. In this regard, scholars (Mudde 2011) have stressed how migrants-related issues are divisive issues that are strongly politicised by right-wing populist parties in order to gain votes (e.g. the Northern League in Italy). Consequently, solidarity towards refugees apparently has become a contentious field that separates people with different political orientations. Unemployment is another sector that can be characterised by a certain degree of contentiousness (Baglioni 2010). The economic crisis and the resulting austerity measures have mobilised Italian trade unions and social movements in defence of the interests and rights of people in economic difficulties, including the unemployed. Disabled persons' organisations mobilised against cuts, too. However, most disability organisations in Italy are composed of disabled people and/or their families and have tended to represent fragmented subsets of people with disabilities (Schianchi 2014), without clear ideologicalpolitical connotations.

On the basis of all these, we hypothesise that:

1. political factors do not matter for solidarity towards the disabled, whereas they matter for solidarity towards refugees and the unemployed;

2. the more an individual is involved in politics and characterised in terms of leftist political orientations and libertarian values, the more she/he will support refugees;

3. the more an individual conceives solidarity in universalistic terms without perceptions of reciprocity and conditionality, the more she/ he will support refugees.

In order to test these research hypotheses, the following variables will be included in the analysis: socio-demographic characteristics (age, gender, education, income, social class) and social traits (social capital measures), 
political factors (interest in politics, party attachment, self-placement on the left-right dimension, libertarian vs. authoritarian values, voting intentions), and religiosity and social beliefs (evaluations on deservingness, reciprocity, conditionality). The chapter will first provide a general picture of a variety of solidarity practices in Italy with respect to our target groups (the disabled, the unemployed, and the refugees), looking at the interrelations between attitudes and behaviours in order to comparatively assess the specificities of each target group. Secondly, through multivariate regression models, it will provide pertinent explanation to investigate the (different) determinants of solidarity activities among the three target groups. Findings show that the most important factors fostering solidarity practices in Italy are social capital, religiosity, cognitive political involvement, and perceptions of deservingness. There are also group-specific triggers of solidarity: political factors play a more important role for support towards the unemployed and (especially) refugees compared to support for the disabled; solidarity towards refugees is clearly an unconditioned form of solidarity.

\section{Italians and Solidarity: An Overall Picture}

Answering the research questions we presented in the introduction and testing our hypotheses require outlining the profiles of Italians engaged in solidarity with our specific target groups (the refugees, the unemployed, and the people with disabilities), taking into account their sociodemographic characteristics, social traits, political attitudes, ideologies and voting intentions, social beliefs, and cultural orientations. Prior to this discussion, we need to contextualise solidarity practices in the general picture of solidarity in Italy through the analysis of the dependent variables of the study: reported solidarity practices towards refugees, the unemployed, and people with disabilities. Our survey includes a battery of questions that allow comparing levels of solidarity with various reference groups and painting a differentiated picture of diverse practices (donating time or money, passive and active membership, buying products, protest participation) that help to mirror both the philanthropic and political dimension of solidarity (see Table 6.1).

The results show that around half of respondents have been engaged in solidarity activities involving people with disabilities (including donating money or time, protesting, and engaging in voluntary associations), whereas $35.5 \%$ engage in solidarity activities with the unemployed and 
Table 6.1 Type of reported solidarity activities in favour of three target groups (in \%)

\begin{tabular}{|c|c|c|c|}
\hline & Refugees & Unemployed & Disabled \\
\hline Attended a march, protest, or demonstration & 5.8 & 11.6 & 8.4 \\
\hline Donating money & 11.0 & 11.3 & 26.5 \\
\hline Donating time & 7.5 & 9.0 & 13.7 \\
\hline $\begin{array}{l}\text { Bought or refused to buy products in support to the } \\
\text { goals }\end{array}$ & 8.1 & 11.1 & 14.5 \\
\hline Engaged as passive member of an organisation & 3.5 & 4.9 & 6.1 \\
\hline Engaged as active member of an organisation & 5.6 & 6.2 & 8.3 \\
\hline Total & 27.6 & 35.5 & 49.4 \\
\hline$N$ & 576 & 741 & 1030 \\
\hline
\end{tabular}

Table 6.15 in Appendix presents the original wording of the survey's questions used for all tables in this chapter

Table 6.2 Reported solidarity activities in order to support the rights of people/groups in different contexts (in \%)

\begin{tabular}{ll}
\hline & Italy \\
\hline In your country & 46.7 \\
In a country in the EU & 31.7 \\
Outside the EU & 32.8 \\
Total $N$ & 2087 \\
\hline
\end{tabular}

At least one of the following actions was named: protest, donate money or time, bought or boycotted goods, passive or active membership

$27.6 \%$ with refugees. ${ }^{2}$ The disability field is the most "crowded" field in terms of solidarity engagement. If we look at the different types of solidarity practices, political protest-oriented activities are carried out especially in favour of the unemployed (11.6\%), whereas the other two fields seem to be less contentious. Conversely, charity behaviour definitely characterises solidarity actions towards the disabled: $26.5 \%$ donate money (compared to $11 \%$ of those who donate money for refugees or the unemployed), and $13.7 \%$ donate time. Similar patterns can be found regarding the active involvement in volunteering, with around 6\% volunteering in favour of refugees or the unemployed and $8 \%$ in favour of people with disabilities. Regarding solidarity towards refugees, after donating money, the most frequent activity $(8.1 \%)$ is a relatively more political one, that is, buying or refusing to buy products in favour of refugees.

Looking at solidarity practices oriented to people/groups in Italy and abroad (see Table 6.2) makes the picture more interesting. 
Table 6.3 Importance of development aid from the EU to assist certain countries outside the EU in their fight against poverty and in support of their development (in \%)

\begin{tabular}{ll}
\hline & Italy \\
\hline Not at all & 3.5 \\
Not very & 6.9 \\
Neither & 18.3 \\
Fairly important & 45.6 \\
Very important & 25.7 \\
Total & 100 \\
$N$ & 2087 \\
\hline
\end{tabular}

Table 6.4 Evaluations of solidarity-based public policies (in \%)

\begin{tabular}{lll}
\hline & & Italy \\
\hline Importance of eliminating big inequalities in & Not at all important & 1.4 \\
income between citizens & Not very important & 3.0 \\
& Neither & 14.9 \\
& Fairly important & 40.0 \\
& Very important & 40.7 \\
& Total & 100 \\
& N & 2087 \\
Agreement on EU pooling funds to help EU & Strongly disagree & 5.2 \\
& Disagree & 11.2 \\
& Neither & 17.6 \\
& Agree & 47.4 \\
& Strongly agree & 18.7 \\
& Total & 100 \\
& $N$ & 1928 \\
\hline
\end{tabular}

Around half of the Italian sample reports having been engaged in solidarity activities for people in their country, whereas Italian citizens are less inclined to support European and transnational solidarity. One-third of respondents have engaged in activities in support of the rights of people in other EU countries or outside the EU.

Moving to describe the attitude towards helping people in developing countries, data show that a strong majority of respondents in Italy supports the attempts of the EU to help countries outside Europe in fighting poverty and promoting development, with $72 \%$ supporting and only $11 \%$ opposing these measures (see Table 6.3).

Finally, it is interesting to look at public support of redistributive policies and of fiscal solidarity among EU member states (see Table 6.4), which have been taken as a measure for "vertical solidarity" (Alesina and 
Giuliano 2011), and thus for the readiness of people to finance and endorse public programmes sharing wealth with the needy. It can be argued that people with redistributional preferences might be more likely involved in solidarity practices. Italian citizens strongly support solidaritybased (redistributive) public policies with $81 \%$ considering the reduction of big income inequalities as an important goal. In other words, the traditional European social model is definitely not questioned by our interviewees. Italians are inclined also to support solidarity-based policies among EU member states, even if to a lesser extent. A large majority supports fiscal solidarity measures towards countries with public debts $(65 \%$ vs. 16\%), with $18 \%$ undecided respondents, probably because Italy has the second largest public debt in the EU. Therefore, this might be also a selfinterested solidarity attitude.

Against this general picture, we focus the analysis on the relationships between solidarity actions and the aforementioned set of individual characteristics: (1) socio-demographics and social traits, (2) political attitudes and behaviours, and (3) social beliefs and religiosity.

\section{Solidarity Actions, Socio-demographic Characteristics, and Social Traits}

Regarding basic socio-demographic characteristics (see Table 6.5), we can observe a difference in terms of age between support for refugees and the unemployed (where there is an over-representation of the youngest age groups-18-35 years old-with respect to the sample's average) on the one hand and support for the disabled on the other hand (where the distribution of age groups is substantially in line with the average). Regarding gender, most people engaged in solidarity activities (in all fields) are male, whereas in the whole sample most respondents are female. This result confirms findings of some studies, which unveil that voluntary engagement tends to replicate the public/private divide by centring on male-dominated activities (Neill and Gidengil 2006; Valentova 2016). The male over-representation is accentuated within the unemployment field $(54.3 \%)$, while the disability field is the most gender balanced $(50.7 \%$ male $)$.

Considering educational attainment, in all the fields, almost half of respondents have a low education level. Nonetheless, higher level of education makes it more likely that people show solidarity. This is true 
Table 6.5 Solidarity actions towards target groups by basic socio-demographic characteristics (in \%)

\begin{tabular}{llllll}
\hline & & $\begin{array}{l}\text { Refugees } \\
\text { support }\end{array}$ & $\begin{array}{l}\text { Unemployed } \\
\text { support }\end{array}$ & $\begin{array}{l}\text { Disabled } \\
\text { support }\end{array}$ & Total \\
\hline Age & 18-24 years & 9.2 & 8.2 & 6.6 & 7.2 \\
& 25-34 years & 18.4 & 17.0 & 13.2 & 14.3 \\
& 35-44 years & 18.3 & 19.8 & 17.2 & 17.6 \\
& 45-54 years & 14.7 & 17.6 & 18.6 & 18.9 \\
& 55-64 years & 22.5 & 22.0 & 24.6 & 23.7 \\
& 65 years and older & 17.0 & 15.6 & 19.8 & 18.3 \\
& Total & 100 & 100 & 100 & 100 \\
Gender & N & 576 & 741 & 1030 & 2087 \\
& Male & 51.7 & 54.3 & 50.7 & 48.0 \\
& Female & 48.3 & 45.8 & 49.3 & 52.0 \\
& Total & 100 & 100 & 100 & 100 \\
& N & 576 & 741 & 1030 & 2087 \\
& Higher education & 17.6 & 15.8 & 13.7 & 12.3 \\
& Intermediate & 33.4 & 34.9 & 36.6 & 35.2 \\
& education & & & & \\
& Lower education & 49.1 & 49.3 & 49.7 & 52.5 \\
& Total & 100 & 100 & 100 & 100 \\
& N & 576 & 741 & 1030 & 2087 \\
\hline
\end{tabular}

especially in solidarity activities concerning refugees and the unemployed. Indeed, the percentage of respondents with higher education is around $18 \%$ among people supporting refugees (vs. $12.3 \%$ of the total population) and around $16 \%$ among people supporting the unemployed.

Table 6.6 reports solidarity actions towards target groups by monthly income level (in euro) and subjective social class. Respondents with the highest income level (3781 euro or more per month) are over-represented among people supporting refugees with respect to the average $(9 \%$ vs. 6\%), whereas respondents with the lowest income level (0-1305 euro) are under-represented (24\% vs. $28 \%)$. This pattern is less pronounced in the unemployment and disability fields. Quite interesting patterns emerge if we take "social centrality" into examination, as measured by perceived class belonging. Results confirm the specificity of solidarity activities in favour of refugees. Among people supporting refugees, the lower class and, above all, the working class are under-represented compared to the total population, whereas the upper middle class is over-represented. 
Table 6.6 Solidarity actions towards target groups by income level and subjective social class (in \%)

\begin{tabular}{|c|c|c|c|c|c|}
\hline & & $\begin{array}{l}\text { Refugees } \\
\text { support }\end{array}$ & $\begin{array}{l}\text { Unemployed } \\
\text { support }\end{array}$ & $\begin{array}{l}\text { Disabled } \\
\text { support }\end{array}$ & Total \\
\hline \multirow[t]{7}{*}{ Income } & 0-1305 euro & 24.0 & 27.4 & 25.5 & 28.1 \\
\hline & $\begin{array}{l}1306-1920 \\
\text { euro }\end{array}$ & 27.7 & 25.6 & 24.6 & 26.2 \\
\hline & $\begin{array}{l}1921-2665 \\
\text { euro }\end{array}$ & 21.7 & 24.6 & 24.6 & 22.9 \\
\hline & $\begin{array}{l}2666-3780 \\
\text { euro }\end{array}$ & 17.5 & 15.4 & 17.7 & 16.6 \\
\hline & $\begin{array}{l}3781 \text { euro or } \\
\text { more }\end{array}$ & 9.1 & 7.0 & 7.6 & 6.2 \\
\hline & Total & 100 & 100 & 100 & 100 \\
\hline & $N$ & 522 & 677 & 922 & 1803 \\
\hline \multirow{9}{*}{$\begin{array}{l}\text { Subjective social } \\
\text { class }\end{array}$} & Upper class & 0.2 & 0.2 & 0.3 & 0.2 \\
\hline & $\begin{array}{l}\text { Upper middle } \\
\text { class }\end{array}$ & 7.9 & 5.4 & 5.8 & 4.3 \\
\hline & Middle class & 42.1 & 40.4 & 42.0 & 40.4 \\
\hline & $\begin{array}{l}\text { Lower middle } \\
\text { class }\end{array}$ & 28.9 & 28.5 & 28.7 & 27.2 \\
\hline & Working class & 10.6 & 13.4 & 12.4 & 15.9 \\
\hline & Lower class & 9.2 & 11.2 & 10.0 & 11.5 \\
\hline & Other class & 1.1 & 1.0 & 0.8 & 0.5 \\
\hline & Total & 100 & 100 & 100 & 100 \\
\hline & $N$ & 562 & 730 & 1008 & 2016 \\
\hline
\end{tabular}

Finally, our survey includes some specific questions regarding social capital framework. According to the framework adopted by the OECD (Scrivens and Smith 2013), there are several dimensions of social capital. We focus here just on two aspects: social trust and personal relationships. The first refers to the measure based on the standard question: "Generally speaking, would you say that most people can be trusted or that you need to be very careful in dealing with people?" Trust is measured on a scale of 0 (minimum trust) to 10 (maximum trust). In order to make crosstabulations more readable, we have recoded this variable by considering values between 0 and 4 as absence of trust in others, 5 as neutral position, and, finally, those between 6 and 10 as trust in others.

The second aspect of social capital refers to the "structure and nature of people's personal networks" (Scrivens and Smith 2013, p. 21) and is concerned with whom people know and what they do to establish and maintain 
Table 6.7 Solidarity actions towards target groups by social capital (in \%)

\begin{tabular}{|c|c|c|c|c|c|}
\hline & & $\begin{array}{l}\text { Refugees } \\
\text { support }\end{array}$ & $\begin{array}{l}\text { Unemployed } \\
\text { support }\end{array}$ & $\begin{array}{l}\text { Disabled } \\
\text { support }\end{array}$ & Total \\
\hline \multirow[t]{5}{*}{ Social trust } & $\begin{array}{l}\text { People cannot } \\
\text { be trusted }\end{array}$ & 38.8 & 46.3 & 46.7 & 51.2 \\
\hline & Neutral & 18.3 & 18.1 & 18.6 & 20.0 \\
\hline & $\begin{array}{l}\text { People can be } \\
\text { trusted }\end{array}$ & 42.8 & 35.6 & 34.7 & 28.8 \\
\hline & Total & 100 & 100 & 100 & 100 \\
\hline & $N$ & 570 & 736 & 1021 & 2041 \\
\hline \multirow[t]{6}{*}{$\begin{array}{l}\text { Frequency of } \\
\text { meetings with friends }\end{array}$} & $\begin{array}{l}\text { Less than once } \\
\text { this month }\end{array}$ & 22.1 & 23.5 & 27.3 & 33.3 \\
\hline & $\begin{array}{l}\text { Once or twice } \\
\text { this month }\end{array}$ & 35.4 & 36.9 & 36.1 & 34.4 \\
\hline & Every week & 35.1 & 32.7 & 30.6 & 26.9 \\
\hline & $\begin{array}{l}\text { Almost every } \\
\text { day }\end{array}$ & 7.5 & 6.9 & 6.0 & 5.4 \\
\hline & Total & 100 & 100 & 100 & 100 \\
\hline & $N$ & 576 & 741 & 1030 & 2087 \\
\hline
\end{tabular}

their personal relationships. Meeting socially with friends at least once a week is a well-established measure of this phenomenon (e.g. European Social Survey).

Results seem to confirm the relevance of social capital for solidarity actions (see Table 6.7). As for solidarity actions towards all target groups, people who trust others are clearly over-represented compared to the total population. Indeed, on average $29 \%$ of the sample trust in others, whereas this percentage increases at $35 \%$ among people supporting the disabled, at $36 \%$ among people supporting the unemployed, and at $43 \%$ among people supporting refugees. In the latter case, more people trust in others than do not trust in others. It follows that solidarity towards foreigners is strongly associated with a generalised trust in human beings.

A similar pattern is depicted by the second measure of social capital related to the frequency of social connections. Among people engaging in solidarity activities in favour of all target groups, those meeting socially with friends at least every week are strongly over-represented compared to the total population, whereas those who meet less than once a month are strongly under-represented (especially among those supporting refugees and unemployed). 


\section{Solidarity Actions and Political Factors}

Previously, we mentioned that solidarity has not only a philanthropic dimension but also a political one. Therefore, it is important to look at the relationship between solidarity actions and politics, in particular looking at respondents' attitudes towards politics, their self-placement along the leftright spectrum and along the libertarian-authoritarian dimension, and their voting intentions.

The respondents' attitudes towards politics are derived from their interest in politics and party attachment (see Table 6.8). The level of cognitive political involvement of respondents can be measured on a four-point scale by their interest in politics. On average, those that are very or somewhat interested in politics are $64 \%$. This percentage remarkably increases among people who are engaged in solidarity practices: $74 \%$ as for refugees, $75 \%$ as for the unemployed, and $70 \%$ as for the disabled. Another measure of involvement in politics is the psychological feeling of attachment towards a party, which is also an important explanatory variable of voting behaviour (Campbell et al. 1960). Results strengthen what we have previously seen: political involvement seems to be associated with engagement in solidarity actions. Indeed, on average those who say they are close to a party are $76 \%$. Among people engaging in solidarity actions, this percentage increases, ranging from $81 \%$ within the disability field to $85.5 \%$ within the unemployment field. Research has stressed the linkage between cognitive involvement in politics and political participation. For instance, low levels of cognitive engagement in politics and the withdrawal from political parties

Table 6.8 Solidarity actions towards target groups by political involvement (in \%)

\begin{tabular}{llllll}
\hline & & $\begin{array}{l}\text { Refugees } \\
\text { support }\end{array}$ & $\begin{array}{c}\text { Unemployed } \\
\text { support }\end{array}$ & $\begin{array}{l}\text { Disabled } \\
\text { support }\end{array}$ & Total \\
\hline Political & Not at all interested & 6.0 & 6.4 & 7.0 & 11.5 \\
interest & Not very interested & 20.0 & 18.4 & 22.7 & 24.5 \\
& Quite interested & 46.8 & 47.9 & 45.8 & 43.7 \\
& Very interested & 27.2 & 27.2 & 24.6 & 20.3 \\
& Total & 100 & 100 & 100 & 100 \\
\multirow{5}{*}{ Party } & $N$ & 565 & 730 & 1011 & 2024 \\
attachment & No party & 15.7 & 14.5 & 19.0 & 23.9 \\
& Close to a party & 84.3 & 85.5 & 81.0 & 76.1 \\
& Total & 100 & 100 & 100 & 100 \\
& $N$ & 537 & 690 & 967 & 1911 \\
\hline
\end{tabular}


are important factors explaining young people's lower involvement in institutional (and non-institutional) political participation (García-Albacete 2014). Political interest is also an important explanatory factor of young people's voting behaviour (Maggini 2016). Our data show that political involvement is also associated with civic engagement through solidarity activities. This is not surprising, given that civic engagement refers to "actions and behaviours that can be seen as contributing positively to the collective life of a community or society" (Scrivens and Smith 2013, p. 28), including activities such as political participation.

At this point, what about the relationship between political selfplacement on the left-right scale and solidarity actions in favour of different target groups? The political self-placement of respondents has been measured from 0 to 10 , with the value of 0 corresponding to the far left and the value of 10 corresponding to the far right. Consequently, we have considered values between 0 and 4 as "centre left", 5 as "centre", those between 7 and 10 as "centre right", and, finally, missing values as "not self-placed" (see Table 6.9). These data show that the ideological character of people supporting the disabled is very similar to the total population's. There is a substantial equilibrium between centre-left and centre-right people. Conversely, centre-left people are over-represented among people supporting the unemployed (37\% vs. $33 \%$ of the whole sample) and, especially, among people supporting refugees (41\% vs. $33 \%$ ).

Table 6.9 Solidarity actions towards target groups by left-right self-placement and libertarian-authoritarian index (in \%)

\begin{tabular}{llllll}
\hline & & $\begin{array}{l}\text { Refugees } \\
\text { support }\end{array}$ & $\begin{array}{l}\text { Unemployed } \\
\text { support }\end{array}$ & $\begin{array}{l}\text { Disabled } \\
\text { support }\end{array}$ & Total \\
\hline Left-right & Centre left & 40.7 & 37.0 & 35.5 & 33.4 \\
self-placement & Centre & 17.9 & 16.3 & 17.0 & 15.6 \\
& Centre right & 31.1 & 34.1 & 34.4 & 33.0 \\
& Not & 10.4 & 12.6 & 13.0 & 18.0 \\
& self-placed & & & & \\
& Total & 100 & 100 & 100 & 100 \\
Libertarian- & N & 576 & 741 & 1030 & 2087 \\
authoritarian index & Authoritarian & 34.1 & 39.5 & 41.1 & 42.1 \\
& Neutral & 25.3 & 22.6 & 23.9 & 22.3 \\
& Libertarian & 40.6 & 37.9 & 35.0 & 35.7 \\
& Total & 100 & 100 & 100 & 100 \\
& N & 490 & 626 & 871 & 1726 \\
\hline
\end{tabular}


This confirms our hypothesis that disability is not a divisive issue in political terms, whereas solidarity engagement in the other two fields is more related to political-ideological elements. Once again, the field of refugees is singled out for its specificity: here, centre-left people are by far the largest category. Finally, it is worth noting that people not self-placed on the left-right scale are under-represented in all fields, signalling again the positive linkage between political involvement and civic engagement in solidarity actions.

Table 6.9 shows the relationship between the libertarian-authoritarian index and solidarity actions, too. Electoral studies have highlighted that new political issues linked to the libertarian-authoritarian dimension have become salient for voters (Thomassen 2005), besides the traditional lines of political contestation (left-right and religion). In our survey, there are several questions connected to a broader libertarian-authoritarian divide, as confirmed by a factor analysis. ${ }^{3}$ Consequently, we created an additive index linked to a unique factor component. This index is an indicator of libertarian values, and we recoded it classifying values between 0 and 4.4 as "authoritarian", values between 4.6 and 5.4 as "neutral", and values between 5.6 and 10 as "libertarian". Findings confirm that disability is not a divisive issue in political terms, whereas solidarity engagement in the unemployment field and, above all, in the refugees field is more related to political values. Indeed, in the latter field people with libertarian values are by far the largest category, whereas within the whole sample people with authoritarian values are the largest category.

Focusing on voting behaviour (see Table 6.10) confirms previous analysis: a difference between centre-left and right-wing parties' voters emerges only among people carrying out solidarity activities in favour of refugees. Indeed, people who vote for centre-left parties (Democratic Party and radical left parties) are over-represented compared to the total population, whereas right-wing voters of Northern League are underrepresented. This is in line with our expectation. Regarding the Five Star Movement, its voters are over-represented among people engaging in solidarity actions. According to several studies, indeed, the Five Star Movement is a web-populist party (Corbetta and Gualmini 2013) appealing for direct democracy and cross-cutting the traditional left-right dimension (Maggini 2014; Tronconi 2015). This also means that among its voters there are people with left-wing values (pro-refugees) as well as right-wing people (anti-migration). The Five Star Movement is the most over-represented among people supporting the unemployed. This is 
Table 6.10 Solidarity actions towards target groups by voting intentions (in \%)

\begin{tabular}{lllll}
\hline & $\begin{array}{l}\text { Refugees } \\
\text { support }\end{array}$ & $\begin{array}{l}\text { Unemployed } \\
\text { support }\end{array}$ & $\begin{array}{l}\text { Disabled } \\
\text { support }\end{array}$ & Total \\
\hline Italian left (SI/SEL) & 3.0 & 3.3 & 2.9 & 2.3 \\
Democratic Party & 20.6 & 16.8 & 19.1 & 18.0 \\
Five Star Movement & 26.7 & 30.8 & 26.2 & 23.9 \\
Popular area & 3.1 & 2.6 & 2.2 & 1.3 \\
Forward Italy & 6.4 & 6.3 & 6.5 & 5.9 \\
Northern League & 8.3 & 10.1 & 10.6 & 10.6 \\
Brothers of Italy & 3.5 & 4.1 & 3.5 & 3.2 \\
Communist Refoundation Party & 2.9 & 2.9 & 1.8 & 1.5 \\
Other party & 4.4 & 3.6 & 3.7 & 3.2 \\
Do not know & 21.1 & 19.6 & 23.6 & 30.2 \\
Total & 100 & 100 & 100 & 100 \\
$N$ & 576 & 741 & 1030 & 2087 \\
\hline
\end{tabular}

consistent with the over-representation of this party among the unemployed, especially young people. Radical left parties are also over-represented in this field, but centre-right voters are in line with the average. Conversely, Democratic Party voters are under-represented. Thus, in the unemployment field, there is not a clear distinction in terms of left and right but a more contingent distinction between voters of opposition parties and voters of the main governing party. ${ }^{4}$ Finally, there is no significant pattern in terms of voting choices regarding solidarity actions towards the disabled.

\section{Solidarity Actions, Social Beliefs, and Religiosity}

In order to provide a complete picture of people engaged in solidarity, it is necessary to also take into account respondents' social beliefs and religiosity.

Conditionality and deservingness can play an important role regarding solidarity among the public (Oorschot 2000, 2006). Previously we have seen that a large majority of Italians support fiscal solidarity measures towards countries with big public debts. Table 6.11 presents the reasons for fiscal solidarity: $52 \%$ of respondents subscribe the idea of reciprocity and deservingness. According to these views, solidarity within the EU is an exchange relation of giving and receiving help; moreover, groups receiving help need to show that they are worth being helped. 
This vision is shared by people engaging in solidarity actions, with no substantial differences among target groups. Only a minority of $20 \%$ claims that it is a moral duty to help other member states in need. Noticeably, this unconditioned form of solidarity is more widespread among people involved in solidarity activities, especially among those helping refugees $(27 \%)$.

As shown in Table 6.11 , this conditionality is confirmed regarding migrants. Only a minority of $8 \%$ is in favour of granting migrants access to social benefits and services immediately on arrival. This is a lower share compared to those who would never grant migrants access to social benefits and services (12\%). Hence, access is conditional on two aspects: they should have worked and paid taxes $(38 \%)$ and they should become citizens of the country $(36 \%)$. A minority $(6.5 \%)$ is more generous, granting migrants access more easily after one year staying in Italy (having worked or not). Conditionality decreases among Italians involved in solidarity activities, especially those active in the field of refugees (as it was predictable). In fact, among people supporting refugees, $28 \%$ show the most generous attitudes compared to $14.2 \%$ among the total population $(22 \%$ among people supporting the unemployed and $18 \%$ among those helping the disabled). Symmetrically, those who say "never" are under-represented in all fields. In addition, among people supporting refugees, those who claim the requisite of citizenship are around 10 percentage points below average. Noteworthy, the largest category remains "after have worked and paid taxes for one year", even in the pro-refugees solidarity field (40\%). To sum up, according to our interviewees, solidarity definitely entails entitlements and mutual obligations; this conditioned solidarity prevails even among those helping people who are not part of the national community as refugees.

In our survey, we asked respondents to name the specific group they would choose for charity donation among the following ones: unemployed people, people with disabilities, migrants, refugees/asylum seekers, and children. We can consider this variable as a proxy for deservingness, arguing that people are more likely to choose as preferred group for charity donation the group they consider more deserving of help. Results show (see Table 6.11) that children are by far the most preferred group for charity donation $(49 \%)$, followed by the disabled (24\%) and the unemployed $(21 \%)$. For Italian citizens, refugees and migrants are definitely the groups less deserving ( $4 \%$ and $2 \%$, respectively). Of course, these percentages increase among those supporting refugees, but, even in this case, the 
Table 6.11 Solidarity actions towards target groups by social beliefs: reciprocity, conditionality, and deservingness (in \%)

\begin{tabular}{|c|c|c|c|c|c|}
\hline & & $\begin{array}{l}\text { Refugees } \\
\text { support }\end{array}$ & $\begin{array}{l}\text { Unemployed } \\
\text { support }\end{array}$ & $\begin{array}{l}\text { Disabled } \\
\text { support }\end{array}$ & Total \\
\hline \multirow[t]{4}{*}{$\begin{array}{l}\text { Reason to state for } \\
\text { financial help for EU } \\
\text { countries in trouble }\end{array}$} & $\begin{array}{l}\text { It is our moral duty } \\
\text { to help other } \\
\text { member states that } \\
\text { are in need }\end{array}$ & 26.8 & 24.5 & 23.4 & 20.2 \\
\hline & Total N & 576 & 741 & 1030 & 2087 \\
\hline & $\begin{array}{l}\text { EU member states } \\
\text { should help each } \\
\text { other; every country } \\
\text { may require help } \\
\text { someday }\end{array}$ & 50.6 & 52.0 & 54.3 & 51.8 \\
\hline & Total N & 576 & 741 & 1030 & 2087 \\
\hline \multirow{7}{*}{$\begin{array}{l}\text { Conditionality: when } \\
\text { should migrants obtain } \\
\text { rights to social benefits } \\
\text { and services? }\end{array}$} & $\begin{array}{l}\text { Immediately on } \\
\text { arrival }\end{array}$ & 13.3 & 10.2 & 8.5 & 7.7 \\
\hline & $\begin{array}{l}\text { After living one year } \\
\text { (worked or not) }\end{array}$ & 14.9 & 11.5 & 9.7 & 6.5 \\
\hline & $\begin{array}{l}\text { After worked and } \\
\text { paid taxes one year }\end{array}$ & 40.3 & 39.3 & 41.0 & 38.3 \\
\hline & After citizenship & 26.5 & 31.2 & 33.5 & 35.7 \\
\hline & Never & 5.0 & 7.8 & 7.2 & 11.8 \\
\hline & Total & 100 & 100 & 100 & 100 \\
\hline & $N$ & 576 & 741 & 1030 & 2087 \\
\hline \multirow{7}{*}{$\begin{array}{l}\text { Preferred charity } \\
\text { group for donation }\end{array}$} & Unemployed & 20.5 & 25.8 & 18.7 & 20.9 \\
\hline & $\begin{array}{l}\text { People with } \\
\text { disabilities }\end{array}$ & 22.5 & 23.3 & 27.4 & 23.8 \\
\hline & Migrants & 6.2 & 4.5 & 3.5 & 2.4 \\
\hline & Refugees & 8.1 & 5.0 & 4.9 & 3.8 \\
\hline & Children & 42.6 & 41.4 & 45.5 & 49.1 \\
\hline & Total & 100 & 100 & 100 & 100 \\
\hline & $N$ & 543 & 708 & 979 & 1898 \\
\hline
\end{tabular}

children, the disabled, and the unemployed are by far more deserving than migrants and refugees. Looking at people supporting the disabled and the unemployed, a stronger correlation emerges between the type of solidarity field and the preferred group for donation, even if children are still the most preferred group. Again, these data confirm that groups receiving help need to be perceived as worth being helped. In this regard, foreigners deserve to be helped to the extent that they become part of the national community, at least through work and paying taxes. 
Table 6.12 Solidarity actions towards target groups by religiosity (in \%)

\begin{tabular}{llllll}
\hline & & Refugees support & Unemployed support & Disabled support & Total \\
\hline Religiosity & Not religious & 30.0 & 30.4 & 29.9 & 33.4 \\
& Neutral & 12.4 & 12.9 & 13.2 & 13.0 \\
Religious & 57.6 & 56.8 & 57.0 & 53.6 \\
Total & 100 & 100 & 100 & 100 \\
$N$ & 573 & 739 & 1024 & 2050 \\
\hline
\end{tabular}

Finally, the profile of solidarity actions towards target groups can vary according to cultural orientations like religiosity ${ }^{5}$ (see Table 6.12). Findings show that among Italians involved in solidarity activities, religious people are definitely over-represented compared to the average, being in all fields around $57 \%$.

To sum up, solidarity towards refugees shows some specificities compared to solidarity towards other groups: it is more dependent on personal skills, resources, and social status, selfless, and linked to leftist/libertarian values.

\section{Explanatory Factors of Solidarity ACtions \\ Towards the Refugees, THE Unemployed, AND THE DisABLED}

This section outlines the results of a multivariate logistic regression analysis. Reported solidarity activities in favour of each target group are the dependent variables. In other words, we have three dichotomous dependent variables (for which 0 signifies "no action", I "at least one action") for each target group. The goal is to investigate the (different) determinants of solidarity activities among the three target groups. Which factors tend to promote (or inhibit) solidarity at the individual level? Is there variance comparing the target groups?

Four models for each target group have been created to answer our research questions. The results of estimation for the first three models are presented in Table 6.13, which includes odds ratios (with standard errors) as well as goodness-of-fit statistics (AIC and BIC coefficients, pseudo- $R$ squared values of Nagelkerke). In logistic regression, the odds ratio compares the odds of the outcome event (providing solidarity) one unit apart on the predictor. We have reported the selected independent variables ${ }^{6}$ by 
Table 6.13 Estimated effects on solidarity actions towards different target groups for some predictors, separated models by blocks of variables

\begin{tabular}{|c|c|c|c|c|c|c|}
\hline & \multicolumn{2}{|c|}{ Refugees } & \multicolumn{2}{|c|}{ Unemployed } & \multicolumn{2}{|c|}{ Disabled } \\
\hline & $\begin{array}{l}\text { Odds } \\
\text { ratio }\end{array}$ & $S E$ & $\begin{array}{l}\text { Odds } \\
\text { ratio }\end{array}$ & $S E$ & $\begin{array}{l}\text { Odds } \\
\text { ratio }\end{array}$ & $S E$ \\
\hline \multicolumn{7}{|l|}{ Model $A$} \\
\hline Age & 0.613 & 0.159 & $0.589^{*}$ & 0.138 & $2.397 * * *$ & 0.544 \\
\hline Gender (female) & 0.979 & 0.104 & $0.762 * *$ & 0.074 & 0.909 & 0.085 \\
\hline Intermediate education & 0.880 & 0.108 & 1.003 & 0.111 & 1.054 & 0.111 \\
\hline High education & $1.424^{*}$ & 0.220 & $1.388^{*}$ & 0.202 & 1.173 & 0.170 \\
\hline Middle class & $0.432 * * *$ & 0.107 & 0.785 & 0.181 & $0.534^{* *}$ & 0.126 \\
\hline Lower middle class & $0.530^{*}$ & 0.136 & 0.955 & 0.228 & $0.611^{*}$ & 0.150 \\
\hline Working class & $0.316^{* * *}$ & 0.0899 & 0.758 & 0.197 & $0.413^{* * *}$ & 0.108 \\
\hline Lower class & $0.428 * *$ & 0.126 & 0.999 & 0.268 & $0.523^{*}$ & 0.141 \\
\hline Other class & 1.321 & 1.078 & 2.44 & 1.852 & 2.059 & 1.781 \\
\hline Social trust & $6.508 * * *$ & 1.438 & $2.196^{* * *}$ & 0.429 & $2.399 * * *$ & 0.439 \\
\hline $\begin{array}{l}\text { Frequency of meeting with } \\
\text { friends }\end{array}$ & $2.428 * * *$ & 0.444 & $2.317 * * *$ & 0.390 & $2.247 * * *$ & 0.378 \\
\hline Constant & $0.344 * * *$ & 0.106 & $0.499 *$ & 0.142 & 0.682 & 0.194 \\
\hline$N$ & 1982 & & 1982 & & 1982 & \\
\hline Pseudo $R^{2}$ & 0.074 & & 0.036 & & 0.035 & \\
\hline$A I C$ & 2197.8 & & 2530.4 & & 2668.6 & \\
\hline$B I C$ & 2264.9 & & 2597.5 & & 2735.7 & \\
\hline \multicolumn{7}{|l|}{ Model B } \\
\hline Age & $0.344 * * *$ & 0.105 & 0.317 ** * & 0.090 & 1.137 & 0.305 \\
\hline Gender (female) & 1.008 & 0.126 & $0.786^{*}$ & 0.093 & 0.974 & 0.111 \\
\hline Intermediate education & 0.761 & 0.108 & 0.892 & 0.119 & 0.983 & 0.124 \\
\hline High education & 1.275 & 0.227 & 1.194 & 0.206 & 0.976 & 0.166 \\
\hline Middle class & 0.428 ** & 0.115 & 0.894 & 0.243 & 0.479 ** & 0.136 \\
\hline Lower middle class & $0.483^{* *}$ & 0.134 & 1.063 & 0.300 & $0.493^{*}$ & 0.143 \\
\hline Working class & $0.327 * * *$ & 0.104 & 1.119 & 0.347 & 0.394 ** & 0.124 \\
\hline Lower class & 0.380 ** & 0.128 & 1.017 & 0.333 & $0.486^{*}$ & 0.160 \\
\hline Other class & 0.653 & 0.539 & 1.833 & 1.409 & 1.053 & 0.837 \\
\hline Political interest & $2.290 * * *$ & 0.531 & $2.924 * * *$ & 0.654 & $2.489 * * *$ & 0.522 \\
\hline Party attachment & $1.793 * *$ & 0.335 & $2.043 * * *$ & 0.368 & 1.288 & 0.201 \\
\hline Left-right self-placement & $0.570^{*}$ & 0.125 & 0.708 & 0.150 & 0.974 & 0.199 \\
\hline Libertarian-authoritarian index & $2.835^{* *}$ & 1.058 & 1.508 & 0.539 & 0.934 & 0.314 \\
\hline Constant & 0.478 & 0.213 & $0.316^{* *}$ & 0.139 & 1.096 & 0.458 \\
\hline$N$ & 1369 & & 1369 & & 1369 & \\
\hline Pseudo $R^{2}$ & 0.056 & & 0.049 & & 0.022 & \\
\hline$A I C$ & 1616.4 & & 1750.8 & & 1864.5 & \\
\hline$B I C$ & 1689.5 & & 1823.9 & & 1937.6 & \\
\hline
\end{tabular}


Table 6.13 (continued)

\begin{tabular}{|c|c|c|c|c|c|c|}
\hline & \multicolumn{2}{|c|}{ Refugees } & \multicolumn{2}{|c|}{ Unemployed } & \multicolumn{2}{|c|}{ Disabled } \\
\hline & $\begin{array}{l}\text { Odds } \\
\text { ratio }\end{array}$ & $S E$ & $\begin{array}{l}\text { Odds } \\
\text { ratio }\end{array}$ & $S E$ & $\begin{array}{l}\text { Odds } \\
\text { ratio }\end{array}$ & $S E$ \\
\hline \multicolumn{7}{|l|}{ Model C } \\
\hline Age & 0.621 & 0.170 & $0.448^{* *}$ & 0.109 & $1.840^{*}$ & 0.443 \\
\hline Gender (female) & 0.951 & 0.108 & 0.741 ** & 0.075 & 0.851 & 0.084 \\
\hline Intermediate education & 0.921 & 0.119 & 1.083 & 0.125 & 1.056 & 0.118 \\
\hline High education & 1.387 & 0.241 & $1.385^{*}$ & 0.219 & 1.106 & 0.173 \\
\hline Middle class & 0.451 * * & 0.117 & 0.836 & 0.204 & $0.576^{*}$ & 0.141 \\
\hline Lower middle class & $0.486^{* *}$ & 0.130 & 0.939 & 0.236 & $0.606^{*}$ & 0.153 \\
\hline Working class & $0.316 * * *$ & 0.095 & 0.848 & 0.233 & 0.431 ** & 0.117 \\
\hline Lower class & $0.384 * *$ & 0.120 & 0.955 & 0.270 & $0.563^{*}$ & 0.158 \\
\hline Other class & 1.808 & 1.212 & 3.147 & 2.168 & 2.814 & 2.200 \\
\hline Religiosity & $1.906 * * *$ & 0.364 & $2.093 * * *$ & 0.359 & $1.989 * * *$ & 0.328 \\
\hline EU help motive: moral duty & $1.339^{*}$ & 0.180 & 1.229 & 0.149 & 1.2 & 0.147 \\
\hline EU help motive: reciprocity & 0.822 & 0.093 & 0.87 & 0.090 & 1.037 & 0.103 \\
\hline $\begin{array}{l}\text { Conditionality for migrants: } \\
\text { after living in Italy for a year }\end{array}$ & $1.720^{*}$ & 0.468 & $1.668^{*}$ & 0.430 & $2.345^{* *}$ & 0.632 \\
\hline $\begin{array}{l}\text { Conditionality for migrants: } \\
\text { after having worked and paid } \\
\text { taxes for a year }\end{array}$ & 0.489 ** * & 0.102 & 0.693 & 0.139 & 1.047 & 0.207 \\
\hline $\begin{array}{l}\text { Conditionality for migrants: } \\
\text { once obtaining citizenship }\end{array}$ & $0.322 * * *$ & 0.069 & $0.579 * *$ & 0.119 & 0.767 & 0.153 \\
\hline $\begin{array}{l}\text { Conditionality for migrants: } \\
\text { never }\end{array}$ & $0.137^{* * *}$ & 0.043 & $0.378^{* * *}$ & 0.098 & $0.441^{* * *}$ & 0.109 \\
\hline $\begin{array}{l}\text { Preferred charity group: the } \\
\text { unemployed }\end{array}$ & 1.169 & 0.168 & $1.825^{* * *}$ & 0.238 & 0.927 & 0.117 \\
\hline $\begin{array}{l}\text { Preferred charity group: the } \\
\text { disabled }\end{array}$ & 1.114 & 0.155 & $1.309^{*}$ & 0.164 & 1.682 *** & 0.210 \\
\hline $\begin{array}{l}\text { Preferred charity group: } \\
\text { migrants }\end{array}$ & $5.374 * * *$ & 1.972 & $3.215^{* * *}$ & 1.084 & $2.453^{*}$ & 0.891 \\
\hline $\begin{array}{l}\text { Preferred charity group: } \\
\text { refugees/asylum seekers }\end{array}$ & 3.284 ** * & 1.027 & 1.618 & 0.445 & $1.772^{*}$ & 0.494 \\
\hline Constant & 1.535 & 0.563 & 0.850 & 0.292 & 0.952 & 0.320 \\
\hline$N$ & 1841 & & 1841 & & 1841 & \\
\hline Pseudo $R^{2}$ & 0.118 & & 0.063 & & 0.057 & \\
\hline$A I C$ & 1990.5 & & 2327.7 & & 2440.1 & \\
\hline$B I C$ & 2106.4 & & 2443.6 & & 2556 & \\
\hline
\end{tabular}

${ }^{*} p<0.05,{ }^{* *} p<0.01,{ }^{* *} p<0.001$ 
blocks: first, the socio-demographic variables and social capital measures; secondly, political factors (political interest, party attachment, left-right self-placement, libertarian-authoritarian index) controlled for sociodemographic characteristics (age, gender, education, social class); and thirdly, social beliefs (evaluations of reciprocity, conditionality, deservingness) and religiosity, again controlled for socio-demographic characteristics. Thus, it is possible to assess the contribution given by each group of variables to the model's goodness of fit, compared across target groups. Finally, Table 6.14 presents results for the full model with all independent variables for each target group.

Let us start with the first model. The overall predictive power of model A is quite low, explaining 7\% of variance as for support of refugees and $4 \%$ as for disabled and unemployed support. It means that socio-demographic variables and social traits do not explain sufficiently the solidarity-based behaviour of the respondents. Looking at the $p$ values of the predictors, clearly social traits prevail over basic socio-demographics. Indeed, for each target group, measures of social capital (social trust and frequency of social connections with friends) are both very significant with $p$ at $0.1 \%$. Furthermore, these variables show the highest odds ratios: higher level of social trust and social connections increase the odds of engaging in solidarity actions.

Regarding subjective social class, some categories are very significant with $p$ at $0.1 \%$ : working class as for refugees and the disabled support and middle class as for refugees support (whereas it is significant with $p$ at $1 \%$ for disabled support).

Here, a first difference between target groups emerges: social class is not related to solidarity towards the unemployed, whereas it seems to be related to solidarity towards refugees and the disabled. In the latter instance, all the social class dummies (except the residual category of "other class") are significant with respect to the reference category (upper/ upper middle class). Looking at the odds ratio, belonging to classes different from the highest class decreases the odds of supporting refugees and the disabled.

Concerning socio-demographic characteristics, a high education level (with respect to the low level) increases the odds of supporting refugees and the unemployed (significant with $p$ at $5 \%$ ), whereas education does not matter in support for disability. Age is very significant ( $p$ at $0.1 \%)$ for disabled support and it is significant for unemployed support ( $p$ at $5 \%$ ), but the direction of the effect is the opposite: ageing increases the odds of supporting the 
Table 6.14 Estimated effects on solidarity actions towards different target groups for some predictors, full model

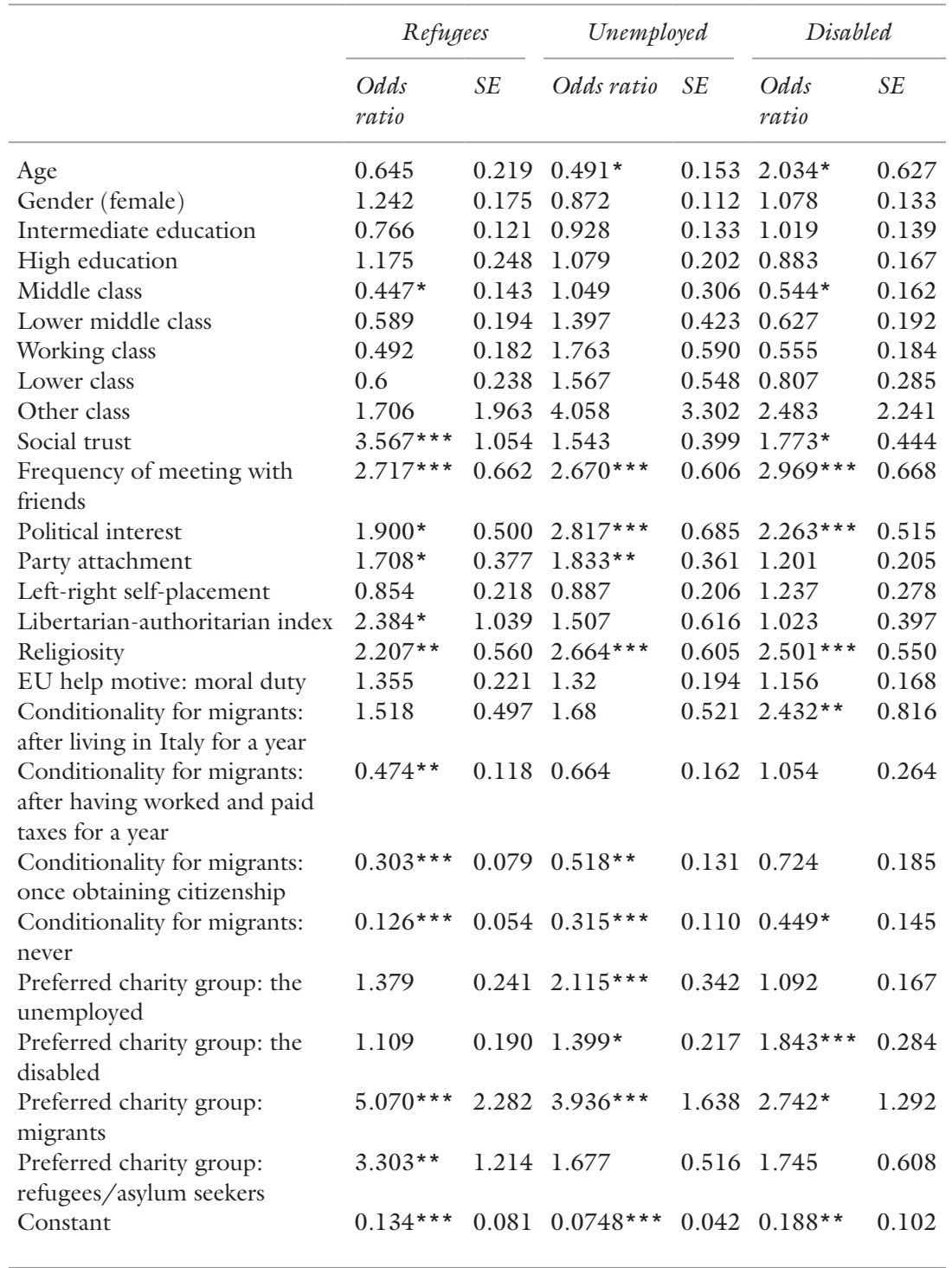


Table 6.14 (continued)

\begin{tabular}{|c|c|c|c|c|c|}
\hline & \multicolumn{2}{|c|}{ Refugees } & Unemployed & \multicolumn{2}{|c|}{ Disabled } \\
\hline & $\begin{array}{l}\text { Odds } \\
\text { ratio }\end{array}$ & $S E$ & Odds ratio $\quad S E$ & $\begin{array}{l}\text { Odds } \\
\text { ratio }\end{array}$ & $S E$ \\
\hline$N$ & 1299 & & 1299 & 1299 & \\
\hline Pseudo $R^{2}$ & 0.179 & & 0.122 & 0.09 & \\
\hline$A I C$ & 1373.6 & & 1569.5 & 1668.6 & \\
\hline$B I C$ & 1508 & & 1703.9 & 1803 & \\
\hline
\end{tabular}

${ }^{*} p<0.05,{ }^{* *} p<0.01,{ }^{* * *} p<0.001$

disabled and decreases the odds of supporting the unemployed. Finally, gender is significant ( $p$ at $5 \%$ ) only as for unemployed support: being male increases the odds of supporting the unemployed.

If we move to model B, the contribution of political factors (controlled for socio-demographics) to the model's goodness of fit is low, with a clear difference between solidarity towards the disabled on the one hand and solidarity towards the other groups on the other. In fact, the model explains $6 \%$ and $5 \%$ of the variance as for refugees and unemployed support, respectively, and only $2 \%$ of variance as for the disabled. This confirms our hypothesis: solidarity towards the disabled is not related to political features, with the exception of the level of cognitive political involvement as measured by interest in politics, which is very significant and positively correlated with solidarity actions in favour of all target groups. The other measure of political involvement (party attachment) is very significant ( $p$ at $0.1 \%$ ) for unemployed support and for refugees support $(p$ at $1 \%)$. Finally, ideology in terms of left and right ( $p$ at $5 \%)$ and, above all, political values in terms of libertarian and authoritarian attitudes ( $p$ at $1 \%$ ) are significant only regarding refugees support. The direction of the effect is in line with our expectations: moving to the right of the political space decreases the odds of supporting refugees, whereas the latter is positively associated with libertarian values. This means that solidarity towards refugees is the most characterised in political terms. This confirms that migration is a politically divisive issue.

So far, social traits and political factors (considered as separate blocks) are not sufficient to explain the solidarity-based behaviour of the respondents, and we have to move to Model $\mathrm{C}$ including social beliefs and religiosity, again controlled for socio-demographic characteristics. This model has a better predictive power, especially regarding support of refugees: $12 \%$ 
of the variance is explained, compared to $6 \%$ for unemployed and disabled support. Looking at $p$ values and odds ratios of predictors, we can notice similarities and differences between target groups as for explanatory factors of solidarity practices. Concerning similarities, it seems that religiosity is a good predictor of involvement in solidarity actions, regardless of the target group. Indeed, it is always very significant and odds ratios are high.

Regarding the reasons to support fiscal solidarity among EU member states, the dummy variable measuring reciprocity in help is not statistically significant, as well as the variable measuring an unconditioned form of solidarity ("it is our moral duty to help"), except for refugees support. In this latter instance, believing in an unconditioned form of solidarity towards EU countries in need increases the odds of supporting refugees (with $p$ at $5 \%$ ).

The fact that people supporting refugees have an unconditioned conception of solidarity is confirmed when migrants' entitlements to social benefits are taken into account: with respect to the reference category (granting access to social benefits and services immediately on arrival), both requisites of working/paying taxes and citizenship decrease in a significant way the odds of supporting refugees. Conversely, such dummies are not statistically significant for unemployed and disabled support, except citizenship-related conditionality that decreases the odds of supporting the unemployed with $p$ at $1 \%$. In addition, a tenuous form of conditionality (granting rights after living in Italy for a year) increases the odds of supporting of all target groups, especially the disabled ( $p$ at $1 \%$ ). In this regard, a tenuous form of conditionality is a factor that somehow distinguishes solidarity with different target groups, but in general the absence of conditionality is a factor favouring practices of solidarity, and people against the integration of migrants are very unlikely to be engaged in solidarity actions, regardless of the target group ( $p$ at $0.1 \%$ ).

Considering children as reference category, we notice that citing one of our target groups as the preferred charity group strongly increases the odds of supporting such a group. This occurs especially for the least preferred group by respondents, that is, migrants. Indeed, regardless of the target group, this dummy is always significant, and odds ratios are all very high. This means that a pro-migrants attitude helps solidarity actions in general. Finally, there is a difference between our target groups. Concerning support for refugees, deservingness plays a role only for migrants and refugees dummies (with respect to children). Conversely, as for unemployed support, all dummies are significant (except refugees). As for disabled support, the migrants and refugees dummies are significant in addition to the disabled dummy. 
Finally, we have built a full model including all independent variables (except those that were not significant for any of the target groups) in order to see if previous results are confirmed when controlling for different blocks of independent variables (see Table 6.14). This model provides better goodness-of-fit statistics compared to previous models: it explains $18 \%$ of the variance for support of refugees, $12 \%$ for unemployed support, and $9 \%$ for disabled support. Furthermore, AIC and BIC coefficients are definitely lower (and thus better) compared to separated models.

The full model shows also some important differences compared to separated models. First, gender and education are no longer significant for any of the target groups. Therefore, basic socio-demographic characteristics are not explanatory factors of solidarity practices, except for age in the unemployment and disability field. Ageing significantly increases the odds of supporting the disabled, whereas decreases the odds of supporting the unemployed ( $p$ at $5 \%$ ). It has been shown that younger and older citizens are more active in social movements, according to different levels of "biographical availability" in the life course (Beyerlein and Bergstrand 2013).

Secondly, social class in the full model has lost predictive power. Only being middle class is significant (with $p$ at $5 \%$ ) for refugees and disabled support, with a negative effect compared to the reference category (upper/ upper middle class).

Thirdly, the variable that measures the absence of conditionality for fiscal solidarity among EU member states ("moral duty to help") is no longer significant for refugees support.

In general, however, the full model confirms previous results regarding social capital, political interest, religiosity, conditionality, and deservingness.

First of all, for each target group, both measures of social capital (social trust and frequency of social connections with friends) are still significant, except social trust for unemployed support. Significance is always very high with $p$ at $0.1 \%$, except social trust for disabled support with $p$ at $5 \%$. Furthermore, these variables show high odds ratios: higher levels of social trust and social connections increase the odds of engaging in solidarity actions. This occurs in particular as regards social trust with respect to support for refugees and the frequency of social connections for disabled support: one unit increase in trust in others increases 3.6 times the odds of supporting refugees, and one unit increase in frequency of meeting with friends increases around three times the odds of supporting the disabled. Therefore, our first hypothesis is confirmed: the more an individual is socially embedded and trustworthy of others (the more her/his social capital), the more she/he will support people in need (regardless who are 
these people in need). This is line with previous research that has shown the importance of social capital for solidarity (Putnam et al. 2003; Jenkins 1983; Bourdieu 1986). Indeed, solidarity actions are positively linked to social capital because a high level of interpersonal trust fosters cooperation among individuals and a good frequency of social connections give people access to a wider range of possible support in times of need, producing positive outcomes at a community level (Halpern 2005).

Regarding political factors, the level of cognitive political involvement as measured by interest in politics is a significant variable fostering the odds of being involved in solidarity actions, regardless of the aided group (with high odds ratios between 1.9 and 2.8). The other measure of political involvement (party attachment) is still significant for unemployed support ( $p$ at $1 \%$ ) and for refugees support ( $p$ at 5\%). This confirms our hypothesis that political factors are more related to solidarity towards the unemployed and refugees than to disabled support. Political involvement in terms of interest in politics and party attachment is often associated with civic engagement (Scrivens and Smith 2013). The latter is another element that can help individuals to develop their skills and social values (such as trust in others), and, consequently, it can foster solidarity (Putnam et al. 1994).

Nevertheless, an important difference emerges when political factors are controlled for other blocks of independent variables. Indeed, as regards refugees support, the libertarian-authoritarian index is still significant, whereas the left-right self-placement is no longer significant compared to previous separated model for political variables (Model B). Ideological orientations in terms of left and right are not important predictors of solidarity practices in Italy for any of our target groups, contrary to our expectations based on previous literature (Likki and Staerklé 2014). Conversely, according to our expectations, political values in terms of authoritarian and libertarian attitudes foster solidarity actions towards a specific target group like refugees. This confirms that migrants-related issues are divisive issues that are strongly politicised by right-wing populist parties like the Northern League in order to gain votes (Mudde 2011). Indeed, voters of these parties are often characterised by both authoritarian values on social issues and leftist orientations on economic issues. This also confirms that the libertarian-authoritarian dimension is something different from the traditional left-right dimension, bringing a new set of culture war issues onto the political agenda (Flanagan and Lee 2003). One of these new cultural issues is precisely the migration issue. 
As for traditional cultural orientations, it is conversely confirmed that religiosity is a very good predictor of involvement in solidarity actions, regardless of the target group. Indeed, it is always very significant (with $p$ at $0.1 \%$ or at $1 \%$ ), and odds ratios are high (between 2.2 and 2.7). Definitely, we can say that Italian religious people are more likely to be engaged in solidarity actions. This confirms our expectation based on scholarly writing (Abela 2004; Stegmueller et al. 2012; Lichterman 2015), which has shown the importance of religiosity to explain different levels of solidarity.

With regard to conditionality for migrants' entitlements to social benefits, previous results are generally confirmed: people against the integration of migrants are very unlikely to be engaged in solidarity actions, regardless of the target group, even if this occurs especially for actions in favour of refugees and unemployed people ( $p$ at $0.1 \%)$. Furthermore, both requisites of working/paying taxes and citizenship decrease in a significant way the odds of supporting refugees. Conversely, such dummies are not statistically significant for support of other target groups, except the requisite of citizenship that also significantly decreases the odds of supporting unemployed people. Furthermore, this time a tenuous form of conditionality (granting rights after living in Italy for a year) increases only the odds of supporting the disabled. In this regard, we can say that in general the absence of conditionality is a factor favouring practices of solidarity, especially those towards refugees, whereas people involved in solidarity practices towards the disabled share a tenuous form of conditionality as regards migrants' entitlements to social benefits. Our hypothesis is therefore confirmed: the more an individual conceive solidarity in universalistic terms without perceptions of reciprocity and conditionality, the more she/he will support refugees.

Regarding deservingness, once again, citing one of our target groups as the preferred charity group strongly increases the odds of supporting such a group. Thus, deservingness is definitely a factor fostering solidarity actions in favour of a specific group considered as worth receiving help (Oorshot 2000, 2006), confirming our expectation. Nevertheless, people engaged in solidarity actions are more likely to have positive dispositions not only towards the group they are supporting. This is true especially for people engaged in solidarity actions towards the unemployed: the odds of supporting the unemployed do not depend on a specific preferred charity group. Indeed, all dummies are significant, as previously seen in Model C. Furthermore, once again, a pro-migrants attitude helps solidarity 
actions in general (albeit to a lesser extent when support towards the disabled is taken into consideration). In previous section, we showed that for Italian respondents, migrants are definitely the group less deserving of charity donations. Therefore, we can argue that people mentioning migrants as the preferred charity group are those who share universalistic conceptions of solidarity (i.e. solidarity towards the humankind, not towards a specific target group) and consequently are more likely to support needy people in general, regardless of their ethnic, social, or physical characteristics, as confirmed by our data.

\section{Conclusions}

This chapter aimed to deepen knowledge on solidarity in Italy by providing fresh empirical analyses on solidarity practices with respect to three target groups (the disabled, the unemployed, and refugees) and to explain such solidarity actions with reference to social traits of the respondents, their beliefs, and their political preferences. This study was needed for substantial and theoretical reasons. As regards the first aspect, solidarity is at the centre of the public debate in European societies, drawing the attention of the media, policy-makers, and ordinary citizens. Enduring conflicts among EU member states about financial solidarity with indebted states and a fair burden-sharing in regard to the high numbers of refugees, as well as the rise of xenophobic and populist parties in most European countries, unveil that solidarity is highly contested not only at interstate level but also among European citizens. In this regard, Italy is a relevant case study to explain factors which can strengthen (or inhibit) solidarity actions, because the country in the last years has faced two different crises: the global financial crisis of 2008 that hit hard on Southern European countries and the refugee crisis that since 2014 particularly affected a country positioned at the centre of several migration routes in the Mediterranean Sea. It is evident that in such a difficult landscape, solidarity is particularly under pressure. Hence, understanding factors that foster (or inhibit) solidarity actions towards vulnerable groups that have been strongly affected by different crises can help to shed new light on the most important triggers of interpersonal solidarity in general (working even in contexts of crisis and welfare state retrenchment).

From a theoretical standpoint, previous research has provided a variety of insights, even though it was marked by a number of limitations. First, previous empirical research has privileged the attitudinal dimension of 
solidarity, describing and explaining the disposition to help. Less attention has been paid to the explanation of solidarity practices. Second, much research has focused on public support of redistributive policies (Alesina and Giuliano 2011; Amat and Wibbels 2009; Fong 2001; Rehm 2009), but less knowledge was available in regard to interpersonal forms of solidarity. Furthermore, previous studies have not addressed solidarity-related issues in a systematic manner, focusing only on specific explanatory factors: some have focused on social capital (Putnam et al. 2003; Jenkins 1983), others on social beliefs like perceptions of deservingness (Oorschot 2000, 2006), others on religiosity (Abela 2004; Stegmueller et al. 2012; Lichterman 2015), others on political preferences (Likki and Staerklé 2014), and so on. This study has permitted to fill this gap, providing a comprehensive explanation of social, political, and attitudinal triggers of solidarity practices towards specific groups of needy people.

Throughout the chapter, first we have provided a general picture of a variety of solidarity attitudes and practices in Italy in times of crises; secondly, we have investigated the (different) determinants of solidarity activities towards the three target groups.

The picture of the solidarity activities' context shows that Italians are open to solidarity even in times of crises and this entails to some extent other Europeans and non-Europeans. Furthermore, Italian citizens support the typical redistributive policies of the European social model. Nevertheless, this social model remains strictly linked to the traditional nation state. Indeed, solidarity has a strong political element: it requires, in first instance, that the targets of solidarity are part of the (national) community in terms of citizenship. This citizenship, however, is not a purely formal status but requires shared rights and obligations. Indeed, our findings suggest that most citizens are sceptical about a universalistic and humanitarian conception of solidarity (i.e. solidarity towards human being as such) that entails unconditional solidarity. Overall, for most citizens, solidarity is rights based and thus tied to the notion of citizenship, that is, delimited by legal entitlements and mutual obligations (such as receiving social benefits and paying taxes or contributions). Moreover, groups receiving help need to show that they are worth being helped.

Regarding target groups, the disability field is the most "crowded" field in terms of solidarity engagement, involving around half of respondents. If we look at the different types of solidarity practices, political protest-oriented activities are carried out especially in favour of the unemployed, whereas the other two fields seem to be less contentious, especially the disability field. 
Indeed, charity behaviour definitely characterises solidarity actions towards the disabled. As regards solidarity towards refugees, after the charity behaviour of donating money, the most frequent activity is a relatively more political one, that is, buying or refusing to buy products in support to the goals in favour of refugees. Furthermore, the descriptive analysis shows that solidarity towards refugees displays some specificities compared to solidarity towards other groups: it is more dependent on personal skills, resources, and social status, selfless, and linked to leftist/libertarian values.

As far as the explanatory analysis of the determinants of solidarity activities towards target groups is concerned, findings show that solidarity is a multifaceted phenomenon and its practices can be fostered by a variety of factors: social, political, attitudinal. Hence, focusing only on one kind of these factors would be quite limiting and not sufficient to understand the complexity of reasons underlying the individual choices to support others in need (or, conversely, to not support others). In addition, our analysis shows that there are not only general triggers of solidarity practices but also explanatory factors that are related to specific target groups. As regards similarities between target groups, the most important factors fostering solidarity practices in Italy are social capital, religiosity, cognitive political involvement, and deservingness. Our main hypotheses based on previous research have been confirmed: Italians are more likely involved in solidarity activities (regardless of the target group) when they trust in others and/or have frequent social connections, are religious, and consider the group they are supporting as worth being helped. Another key lesson can be drawn from our analysis: cognitive political involvement measured by interest in politics is another important factor favouring solidarity activities, regardless of the target group. We can argue that this can be the signal, once again, of the importance of social embeddedness. Indeed, people interested in politics are usually individuals characterised by a high level of social resources and civic engagement (Scrivens and Smith 2013). The latter is another element that can help individuals to develop their social capital, and, consequently, it can foster solidarity (Putnam et al. 1994).

As regards group-specific triggers of solidarity, our hypothesis that political factors play a more important role for refugees and unemployed support compared to disabled support has been confirmed. This finding can be explained by the fact that solidarity towards the disabled is not a contested issue in the Italian context and most of the people engaged in disability organisations are not motivated by ideological-political objectives but by philanthropic or personal reasons (for instance, many disability organisations in Italy are composed by people with disabilities and/or their families). 
Furthermore, as expected, libertarian values foster solidarity actions towards refugees. Nevertheless, contrary to our expectations, left-right ideology does not matter when controlled for other variables. This also confirms the specificity of the libertarian-authoritarian dimension compared to the traditional left-right dimension and the importance of new cultural issues (e.g. migration) for contentious politics (Flanagan and Lee 2003). This is particularly important for a country (Italy) that has faced in the last years both economic turmoil and refugee crisis: right-wing populist parties like Northern League (Mudde 2011) have mobilised more on the libertarian-authoritarian dimension than on the economic left-right divide in order to gain votes among the lower classes by using migrants as scapegoating of their fears and economic distress. Therefore, solidarity towards refugees entails political commitment to libertarian values as opposed to authoritarian stances. The fact that solidarity with the unemployed does not separate people with different political orientations in terms of left and right, conversely, can be explained by the over-representation of the Five Star Movement voters among people supporting the unemployed. According to several studies, indeed, the Five Star Movement is a webpopulist party (Corbetta and Gualmini 2013) that cross-cuts the traditional left-right dimension (Maggini 2014; Tronconi 2015).

Finally, another key finding emerges from what has been said so far: solidarity towards refugees shows more specific explanatory factors compared to support for other disadvantaged groups. It is more bounded by political orientations, as above mentioned, and at the same time is clearly an unconditioned form of solidarity. Indeed, it is closely tied to social beliefs like absence of conditionality as regards granting migrants the entitlements to social benefits and services. Conversely, people supporting the disabled are more likely to agree with a tenuous form of conditionality as for migrants' access to social benefits. According to our respondents, refugees and migrants, among our target groups, are those less deserving of charity donations, whereas the disabled is the most preferred group. Consequently, we can argue that solidarity towards refugees entails a more selfless and universalistic conception of solidarity compared to solidarity towards disadvantaged groups (e.g. the disabled) that are considered by the majority of society as worth being helped. In other words, support for refugees can be considered as a specific aspect of solidarity with human beings as such. It should be added that, according to our data, people against the integration of migrants are very unlikely to be engaged in solidarity actions, regardless of the field, and people who mention migrants as preferred charity group for donation are more likely to carry out solidarity activities in favour of all target groups. 


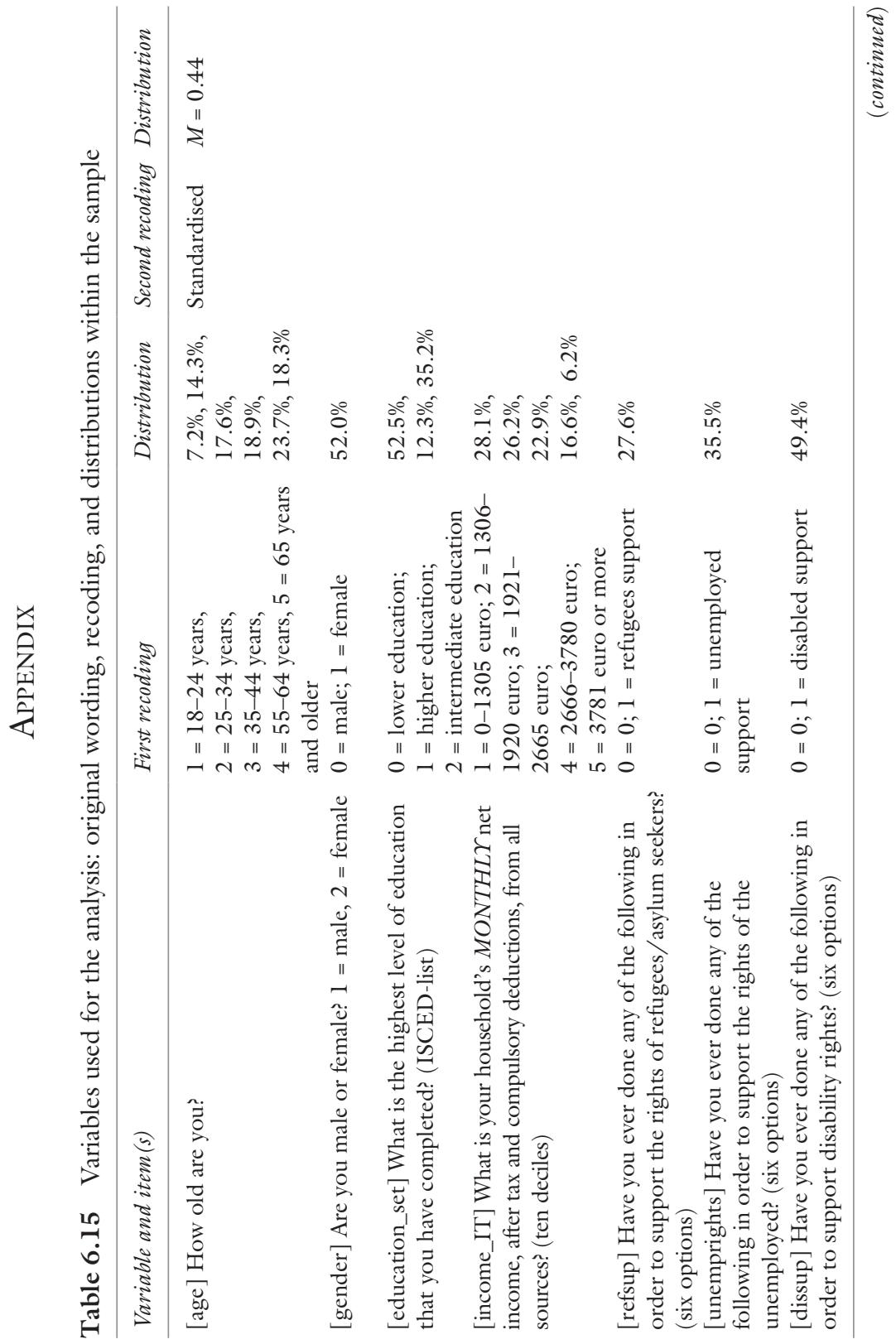




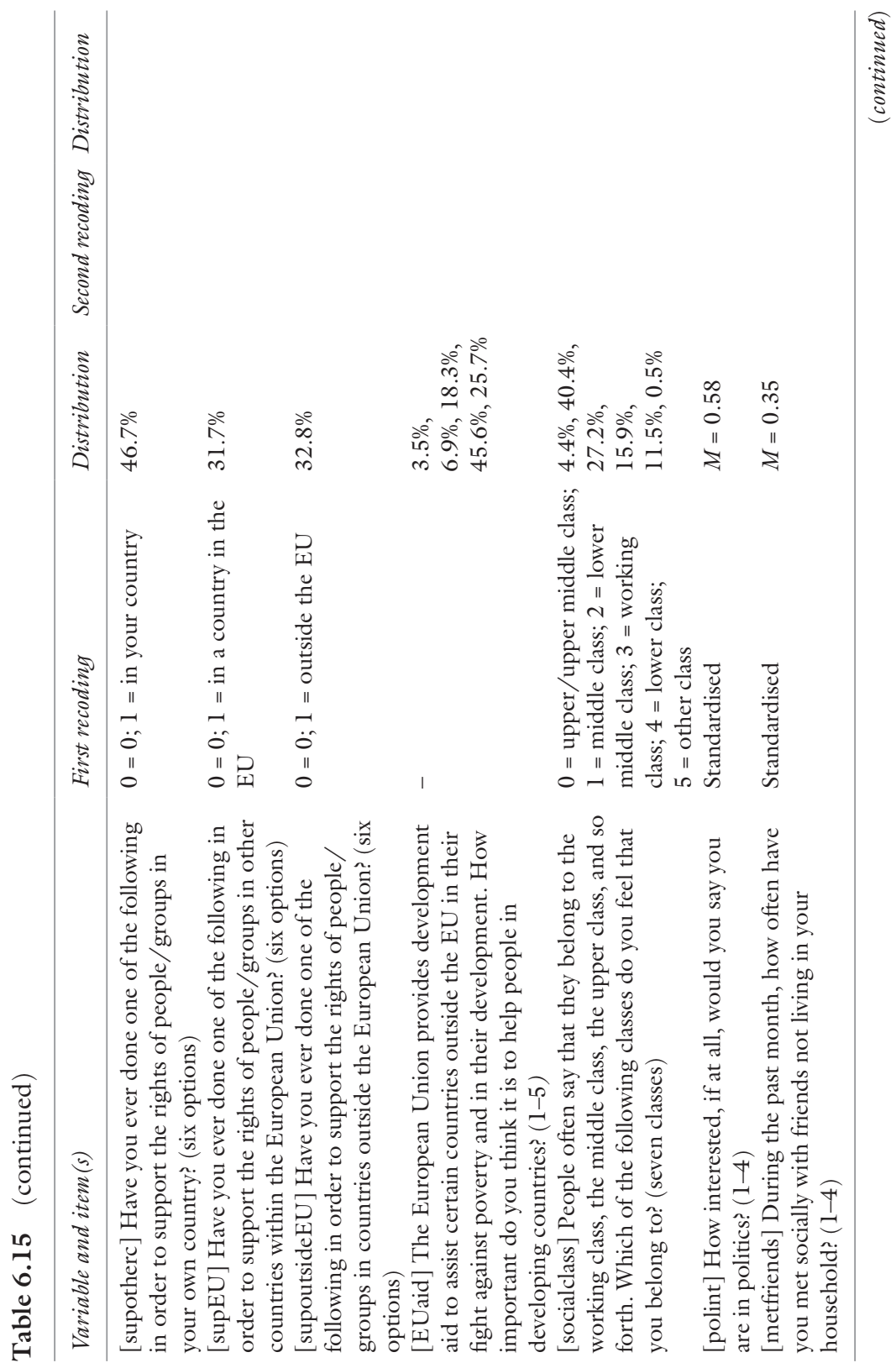




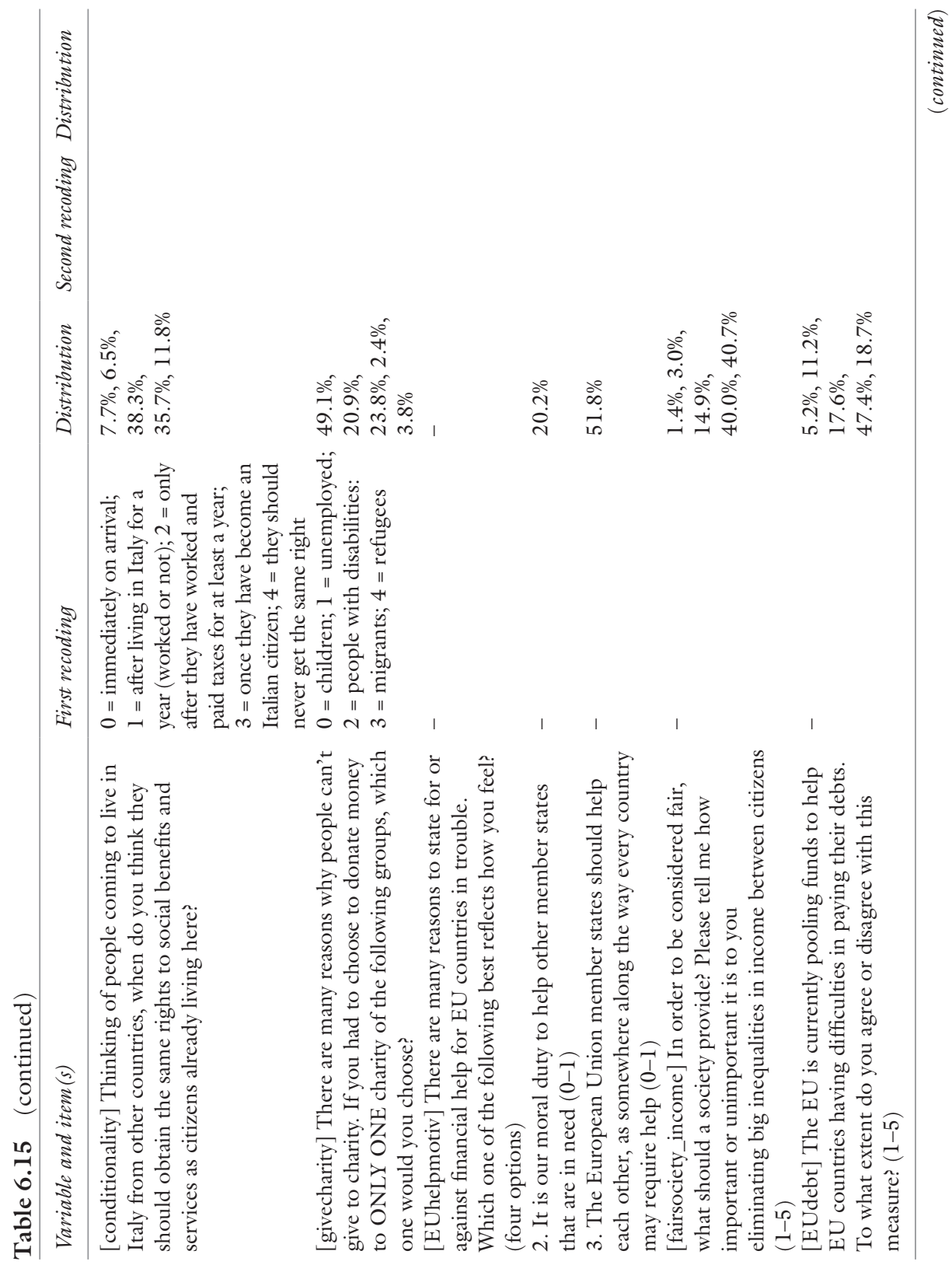




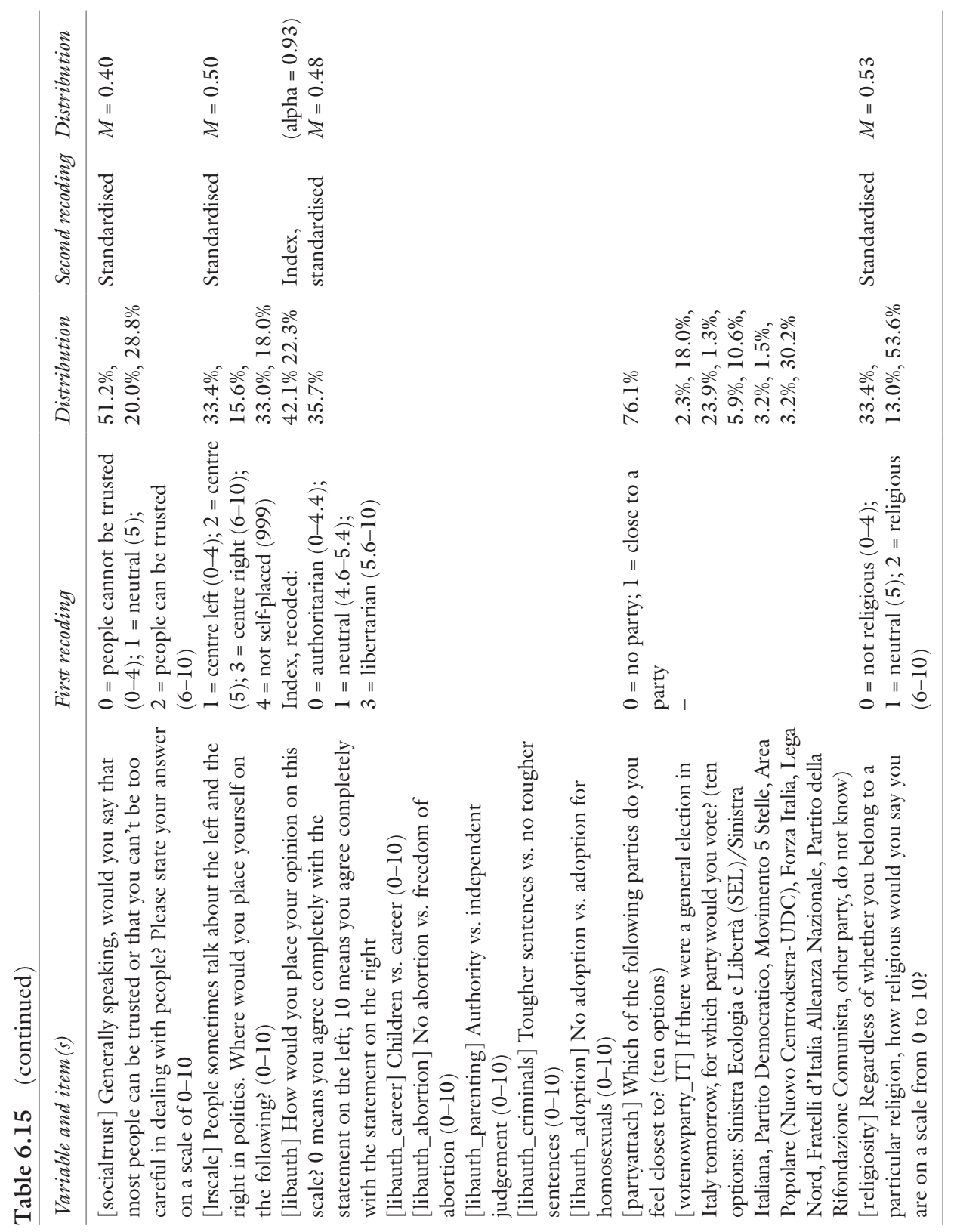




\section{Notes}

1. The initiative was unilaterally launched and financed by the Italian government in October 2013 and ended in December 2014 to rescue migrants in the Mediterranean.

2. Weights have been used for all analyses.

3. In particular, we have run a principal component factor (PCF) analysis including variables measuring respondents' opinions on 0-10 agreement scales linked to several values-related issues: on "women career" versus "children care", on "freedom of abortion" versus "prohibition of abortion", on "child adoption for homosexuals" versus "prohibiting child adoption", on "tougher sentences to fight crime" versus "tougher sentences bring nothing", on "parenting authority" versus "child independent judgement". We detected just one statically significant dimension. Factor loadings were particularly high (between 0.85 and 0.93 ) for all items and the reliability scale was very high (alpha test 0.93 ). Hence, relying on the five above-mentioned items, it is possible to build an additive index of libertarian values.

4. The Democratic Party is in government with minor allies since 2013.

5. This variable measures how religious the respondent is on a scale from 0 to 10 , where 0 stands for "not at all religious" and 10 for "very religious". This variable has been recoded in order to make cross-tabulations more readable by classifying values between 0 and 4 as "not religious", 5 as "neutral", and values between 6 and 10 as "religious".

6. In order to select independent variables, we have looked at the bivariate Pearson's correlations between variables introduced in the previous section for cross-tabulations. According to the strength of the associations (Cohen 1988), we have excluded some variables (e.g. income level, voting choices) in order to avoid items picking up on the same covariance component. Finally, before running logistic regression models, independent variables have been normalised trough rescaling.

\section{REFERENCES}

Abela, A. M. (2004). Solidarity and Religion in the European Union: A Comparative Sociological Perspective. In P. Xuereb (Ed.), The Value(s) of a Constitution for Europe (pp. 71-101). Malta: European Documentation and Research Centre.

Ajzen, I., \& Fishbein, M. (2005). The Influence of Attitudes on Behavior. In D. Albarracín, B. T. Johnson, \& M. P. Zanna (Eds.), The Handbook of Attitudes (pp. 173-221). Mahwah, NJ: Erlbaum. 
Alesina, A., \& Giuliano, P. (2011). Preferences for Redistribution. In J. Benhabib, A. Bisin, \& M. Jackson (Eds.), Handbook of Social Economics (pp. 93-131). San Diego, CA: North-Holland.

Amat, F., \& Wibbels, E. (2009). Electoral Incentives, Group Identity and Preferences for Redistribution. Instituto Juan March de Estudios e Investigaciones, Working Paper 246.

Arendt, H. (1972). Crises of the Republic. New York: Harcourt Brace Jovanovich. Baglioni, S. (2010). The Role of Civil Society Actors in the Contentious Politics of Unemployment. In M. Giugni (Ed.), The Contentious Politics of Unemployment in Europe (pp. 127-151). Basingstoke: Palgrave Macmillan.

Beyerlein, K., \& Bergstrand, K. (2013). Biographical Availability. In D. A. Snow, D. Della Porta, B. Klandermans, \& D. McAdam (Eds.), The Wiley-Blackwell Encyclopedia of Social and Political Movements (pp. 137-138). New York: Wiley-Blackwell.

Blekesaune, M., \& Quadagno, J. (2003). Public Attitudes Toward Welfare State Policies: A Comparative Analysis of 24 Countries. European Sociological Review, $19(5), 415-427$.

Blumer, H. (1955). Attitudes and the Social Act. Social Problems, 3(2), 59-65.

Bourdieu, P. (1986). The Forms of Capital. In J. Richardson (Ed.), Handbook of Theory and Research for the Sociology of Education (pp. 241-258). New York: Greenwood.

Cainzos, M., \& Voces, C. (2010). Class Inequalities in Political Participation and the "Death of Class" Debate. International Sociology, 25(3), 383-418.

Campbell, A., Converse, P. E., Miller, W. E., \& Stokes, D. (1960). The American Voter. New York: Wiley.

Chan, J., To, H.-P., \& Chan, E. (2006). Reconsidering Social Cohesion: Developing a Definition and Analytical Framework for Empirical Research. Social Indicators Research, 75, 273-302.

Cohen, J. (1988). Set Correlation and Contingency Tables. Applied Psychological Measurement, 12(4), 425-434.

Corbetta, P., \& Gualmini, E. (Eds.). (2013). Il partito di Grillo. Bologna: Il Mulino.

Delhey, J. (2007). Do Enlargements Make the European Union Less Cohesive? An Analysis of Trust Between EU Nationalities. Journal of Common Market Studies, 45(2), 253-279.

Festinger, L. (1964). Behavioral Support for Opinion Change. The Public Opinion Quarterly, 28(3), 404-417.

Flanagan, S. C., \& Lee, A.-R. (2003). The New Politics, Culture Wars, and the Authoritarian-Libertarian Value Change in Advanced Industrial Democracies. Comparative Political Studies, 36(3), 235-270.

Fong, C. (2001). Social Preferences, Self-Interest, and the Demand for Redistribution. Journal of Public Economics, 82(2), 225-246. 
García-Albacete, G. (2014). Young People's Political Participation in Western Europe: Continuity or Generational Change? Basingstoke: Palgrave Macmillan.

Giugni, M., \& Passy, F. (Eds.). (2001). Political Altruism? Solidarity Movements in International Perspective. Lanham, MD: Rowman \& Littlefield.

Halpern, D. (2005). Social Capital. Cambridge: Polity Press.

Hechter, M. (1988). Principles of Group Solidarity. Berkeley, CA: University of California Press.

Helliwell, J. F., \& Wang, S. (2010). Trust and Well-being. NBER Working Paper Series No. 15911.

Jeannotte, M. S. (2000). Social Cohesion Around the World: An International Comparison of Definitions and Issues. Paper SRA-390.

Jenkins, J. C. (1983). Resource Mobilization Theory and the Study of Social Movements. Annual Review of Sociology, 9, 527-553.

Lelkes, O. (2010). Social Participation and Social Isolation. Eurostat Methodologies and Working Papers. Luxembourg: EU Publications.

Lichterman, P. (2015). Religion and Social Solidarity. A Pragmatist Approach. In L. Hustinx, J. von Essen, J. Haers, \& S. Mels (Eds.), Religion and Volunteering. Complex, Contested and Ambiguous Relationships (pp. 241-261). Cham: Springer.

Likki, T., \& Staerklé, C. (2014). A Typology of Ideological Attitudes Towards Social Solidarity and Social Control. Journal of Community and Applied Social Psychology, 24, 406-421.

Lochner, K., Kawachi, I., Brennan, R., \& Buka, S. (2003). Social Capital and Neighbourhood Mortality Rates in Chicago. Social Science and Medicine, 56, 1797-1805.

Maggini, N. (2014). Understanding the Electoral Rise of the Five Star Movement in Italy. Czech Journal of Political Science, 21(1), 37-59.

Maggini, N. (2016). Young People's Voting Behaviour in Europe. A Comparative Perspective. London: Palgrave Macmillan.

Mudde, C. (2011). Radical Right Parties in Europe: What, Who, Why? Participation, 34(3), 12-15.

Neill, B., \& Gidengil, E. (Eds.). (2006). Gender and Social Capital. New York: Routledge.

van Oorschot, W. (2000). Who Should Get What, and Why? On Deservingness Criteria and the Conditionality of Solidarity among the Public. Policy \& Politics, 28(1), 33-48.

van Oorschot, W. (2006). Making the Difference in Social Europe: Deservingness Perceptions Among Citizens of European Welfare States. Journal of European Social Policy, 16(1), 23-42.

Putnam, R. D., Leonardi, R., \& Nanetti, R. Y. (1994). Making Democracy Work: Civic Traditions in Modern Italy. Princeton, NJ: Princeton University Press.

Putnam, R. D., Feldstein, L., \& Cohen, D. J. (2003). Better Together: Restoring the American Community. New York: Simon and Schuster. 
Rehm, P. (2009). Risks and Redistribution. An Individual-Level Analysis. Comparative Political Studies, 42(7), 885-881.

Rehm, P., Hacker, J. S., \& Schlesinger, M. (2012). Insecure Alliances: Risk, Inequality, and Support for the Welfare State. American Political Science Review, 106(2), 386-406.

Schianchi, M. (2014). Associations of People with Disabilities in Italy: A Short History. Modern Italy, 19(2), 121-133.

Scrivens, K., \& Smith, C. (2013). Four Interpretations of Social Capital: An Agenda for Measurement. OECD Statistics Working Papers, 2013/06, OECD Publishing.

Stegmueller, D., Scheepers, P., Roßteuscher, S., \& de Jong, E. (2012). Support for Redistribution in Western Europe. Assessing the Role of Religion. European Sociological Review, 28(4), 482-497.

Stjernø, S. (2012). Solidarity in Europe. The History of an Idea. Cambridge: Cambridge University Press.

Svallfors, S. (1997). Worlds of Welfare and Attitudes to Redistribution: A Comparison of Eight Western Nations. European Journal of Sociology, 13(3), 283-304.

Thomassen, J. (Ed.). (2005). The European Voter. Oxford: Oxford University Press.

Tronconi, F. (Ed.). (2015). Beppe Grillo's Five Star Movement: Organisation, Communication and Ideology. Farnham: Ashgate Publishing, Ltd.

Valentova, M. (2016). How Do Traditional Gender Roles Relate to Social Cohesion? Focus on Differences Between Women and Men. Social Indicators Research, 127(1), 153-178.

Verba, S., Nie, N., \& Kim, J. (1978). Participation and Political Equality: A Seven Nation Comparison. London: Cambridge University Press.

Open Access This chapter is licensed under the terms of the Creative Commons Attribution 4.0 International License (http://creativecommons.org/licenses/ by $/ 4.0 /)$, which permits use, sharing, adaptation, distribution and reproduction in any medium or format, as long as you give appropriate credit to the original author(s) and the source, provide a link to the Creative Commons license and indicate if changes were made.

The images or other third party material in this chapter are included in the chapter's Creative Commons license, unless indicated otherwise in a credit line to the material. If material is not included in the chapter's Creative Commons license and your intended use is not permitted by statutory regulation or exceeds the permitted use, you will need to obtain permission directly from the copyright holder.

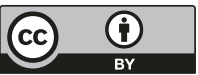

